\title{
Analisis Pengenalan Pola Daun Berdasarkan Fitur Canny Edge Detection dan Fitur GLCM Menggunakan Metode Klasifikasi k-Nearest Neighbor $(\mathrm{kNN})$
}

\author{
(Leaf Pattern Recognition using Canny Edge Detection and GLCM with k-Nearest \\ Neighbor $(k N N))$
}

\author{
Azizah Arif Paturrahman, dan I Gede Pasek Suta Wijaya* \\ Program Studi Teknik Informatika, Fakultas Teknik, Universitas Mataram \\ Jl. Majapahit 62, Mataram, Lombok NTB, INDONESIA \\ Email: azizahariffaturrahman98@yahoo.com,gpsutawijaya@unram.ac.id
}

\section{"Penulis korespondensi}

\begin{abstract}
Leaves are one of the parts of plants that can be applied in the process of identifying species images of leaves. The process of classification of leaf imagery can be done by identifying the image of the leaf shape that can be done by identifying the pattern of the leaf by recognizing the structural characteristics of the leaf such as the shape and texture of the leaf. The classification of this leaf image is based on the canny edge detection and gray-level cooccurrence matrix (GLCM) features using the k-Nearest Neighbor (kNN) classification method. The data used is as many as 350 leaf imagery with seven different species. The results show that from the two extraction features used, the Canny feature gets an accuracy of $80 \%$ and, the GLCM features get an accuracy of $93.3 \%$. And the merging of the two features resulted in increased accuracy of $98 \%$. It can be concluded that this research has produced good accuracy in identifying leaf imagery based on canny edge detection features and Gray-Level Co-occurrence Matrix (GLCM) features and k-Nearest Neighbor classifier method.
\end{abstract}

Key words : leave, canny edge detection, gray-level cooccurence matrix (GLCM), k-nearest neighbor $(\mathrm{kNN})$

\section{Pendahuluan}

Bidang teknologi tentang tumbuhan telah mengalami kemajuan yang pesat, bidang ilmu tumbuhan yang dulunya menjadi cabang ilmu, kini menjadi bidang ilmu yang berdiri sendiri. Morfologi tumbuhan merupakan ilmu tentang tumbuhan yang mempelajari bentuk struktural dari tubuh tumbuhan seperti bentuk dan tekstur dari tumbuhan. Determinasi tumbuhan merupakan proses penentuan klasifikasi jenis tumbuhan berdasarkan ciri morfologi, fisiologis, dan anatomisnya. Pada penelitian ini, klasifikasi tumbuhan dilakukan berdasarkan bentuk morfologi daun. Meningkatnya jumlah flora dan variasinya menyebabkan kemiripan bentuk yang tinggi dan terkadang di temukan kesulitan dalam pengumpulan data daun secara keseluruhan, terutama untuk daun yang berskala besar [1].
Oleh karena itu, pada daun yang memiliki kemiripan yang tinggi, diperlukan identifikasi tekstur untuk proses klasifikasi. Pengklasifikasian otomatis dengan menggunakan sistem komputer ini akan bermanfaat bagi masyarakat peneliti khususnya yang bergerak di bidang khusus seperti produksi jamu, pertanian, perkebunan, dan dokter.

Penelitian yang menggunakan fitur warna daun masih menemui kendala karena daun memiliki warna yang dominan hijau, maka dari itu fitur bentuk dan tekstur dapat digunakan untuk mengidentifikasi citra daun. Kedua fitur ini memuat informasi yang berbeda dan bermanfaat untuk klasifikasi. Penelitian pengenalan pola daun telah dilakukan sebelumnya dengan penelitian daun berdasarkan bentuk dan tekstur yaitu penelitian yang bertujuan untuk memperbaiki fitur citra dengan menggunakan metode kNN dengan penggabungan filter median dan erosi citra dan metode Invariant Moment untuk ekstraksi fitur [2], penelitian klasifikasi daun dengan menggunakan metode Support Vector Machine (SVM) dan melakukan kombinasi dari metode filter Gabor dan matriks Co-Occurrence menghasilkan fitur yang sesuai dengan citra daun tersebut [3], kemudian untuk penelitian lainnya menggunakan metode Local Binary Pattern dan Canny dalam mengklasifikasikan tumbuhan dengan fitur tekstur dan bentuk[1].

Berdasarkan uraian di atas, penggabungan fitur bentuk dan tekstur mendapatkan hasil yang lebih baik dalam mengidentifikasi suatu citra dibandingkan dengan penggunaan fitur bentuk dan tekstur secara terpisah. Oleh karena itu, peneliti melakukan penelitian untuk perancangan sebuah model analisis pengenalan pola daun berdasarkan fitur Canny dan fitur Gray-Level Cooccurence Matrix (GLCM) dengan klasifikasi k-Nearest Neighbors (kNN). Keluaran dari penelitian ini diharapkan dapat mengidentifikasi jenis daun tersebut berdasarkan 
bentuk dan tekstur daun serta dapat mengetahui tingkat keakurasian metode dengan melakukan penggabungan metode ekstraksi fitur Canny dan fitur Gray-Level Cooccurence Matrix (GLCM) menggunakan metode klasifikasi k-Nearest Neighbors (kNN).

\section{TINJAUAN PUSTAKA DAN DASAR TEORI}

\section{A. Tinjauan Pustaka}

Penelitian mengenai identifikasi citra daun telah dilakukan sebelumnya, perbedaan paling menonjol dari setiap penelitian yang telah dilakukan terletak pada dataset, fitur dan metode klasifikasi yang digunakan. Penelitian tersebut antara lain yaitu penelitian tentang identifikasi citra daun menggunakan fitur local binary pattern dan canny edge detection dengan klasifikasi kNN, menghasilkan akurasi pada fitur local binary pattern 94,28\% sedangkan pada fitur canny edge detection lebih tinggi yaitu $98,85 \%[1]$. Selain itu, terdapat penelitian Tentang Identifikasi Jenis Tumbuhan Menggunakan Citra Daun Berbasis Jaringan Saraf Tiruan (Artificial Networks) yang mendapatkan hasil akurasi yaitu 93,6\% [4].

Ekstraksi fitur bentuk menggunakan metode Canny Edge Detection sebelumnya telah dilakukan beberapa kali antara lain yakni penelitian dengan menggunakan metode prewitt dan canny untuk mengidentifikasi ikan air tawar [5]. Hasil dari penelitian tersebut menunjukkan metode canny lebih baik dalam identifikasi citra ikan air tawar dan pada penelitian tentang deteksi tepi daun tembakau dengan menggunakan metode canny menghasilkan akurasi 90\% [6]. Berdasarkan penelitian-penelitian yang telah dilakukan dengan menggunakan metode canny sebagai fitur bentuk, menunjukkan bahwa metode ini optimal dan sangat baik untuk pengenalan pola bentuk, tetapi fitur ini saja tidak cukup untuk pengenalan pola daun, hal ini dikarenakan terdapat kendala dalam pengambilan data secara utuh karena, daun memiliki ukuran yang berbedabeda terutama daun yang memiliki pola yang besar. Oleh karena itu, pada penelitian ini ditambahkan ekstraksi fitur tekstur.

Ekstraksi fitur ciri tekstur pada penelitian ini menggunakan metode Gray Level Co-occurrence Matrix (GLCM) sebelumnya telah dilakukan beberapa kali di antaranya yaitu penelitian tentang pengenalan daging sapi dan daging babi dengan menggunakan metode GLCM sudut $0^{\circ}, 45^{\circ}, 90^{\circ}$ dan $135^{\circ}$ dan klasifikasi Fuzzy Logic menghasilkan tingkat akurasi pada masing-masing sudut $98 \%, 97 \%, 98.5 \%$ dan $98,5 \%$, di mana akurasi yang dihasilkan pada masing-masing sudut tidak memiliki perbedaan yang signifikan. Selain itu, terdapat penelitian tentang Identifikasi Kematangan Buah Apel Dengan menggunakan metode GLCM yang menghasilkan tingkat akurasi sebesar 95\% [7]. Berdasarkan penelitian sebelumnya, metode GLCM mencapai hasil akurasi yang sangat baik dalam ekstraksi fitur tekstur dan penelitian ini dilakukan dengan mengembangkan penelitian sebelumnya dengan menggunakan metode ekstraksi fitur yang berbeda.
Penelitian ini dilakukan dengan penggabungan fitur bentuk dan tekstur, sebelumnya penggabungan metode ini telah menghasilkan beberapa penelitian yaitu penelitian tentang identifikasi citra daun menggunakan fitur local binary pattern dan canny edge detection dengan klasifikasi kNN dengan menghasilkan akurasi 99,42\%[1]. Selain itu, terdapat penelitian tentang Penggabungan Fitur Bentuk dan Fitur Tekstur yang Invariant terhadap Rotasi untuk Klasifikasi Citra Pap Smear hasilnya menunjukkan dengan adanya kombinasi tekstur menghasilkan akurasi 92,44\% [8], maka dari itu dengan melakukan penggabungan mendapatkan akurasi yang lebih baik dibandingkan klasifikasi dengan ekstraksi fitur terpisah dan kedua fitur bentuk dan tekstur memuat informasi yang berbeda sehingga bermanfaat untuk klasifikasi.

Teknik klasifikasi menggunakan metode k-Nearest Neighbor (kNN) sebelumnya telah dilakukan beberapa penelitian di antaranya pada penelitian tentang klasifikasi daun yang memperoleh tingkat akurasi 86,67\% [2], penelitian tentang klasifikasi jenis kayu menggunakan ekstraksi fitur histogram dan klasifikasi kNN memperoleh tingkat akurasi 91\%[9] dan penelitian tentang identifikasi citra kupu-kupu dengan menggunakan deteksi tepi canny dan klasifikasi kNN menghasilkan tingkat akurasi $80 \%$ [10]. Penggunaan metode $\mathrm{kNN}$ ini untuk melakukan klasifikasi sudah banyak digunakan karena metode ini menghasilkan akurasi yang cukup ideal dalam pengklasifikasian citra berdasarkan jumlah ketetanggaan terdekat dan lebih efektif serta menghasilkan data yang lebih akurat pada jumlah data training yang besar.

Berdasarkan penelitian-penelitian yang telah di uraikan tersebut, dapat diketahui bahwa metode Canny Edge Detection, Gray Level Co-occurance Matrix (GLCM) dan metode klasifikasi k-Nearest Neighbor dapat memperoleh hasil yang baik dalam pendeteksian dan pengklasifikasian citra. Oleh karena itu, peneliti bermaksud untuk menggunakan metode ini untuk analisis pengenalan pola daun.

\section{B. Dasar Teori}

\section{B.1.Citra Digital}

Citra digital merupakan citra yang berupa diskrit, baik koordinat ruang ataupun intensitas cahayanya, yang tadinya ialah citra yang kontinu. Citra digital dinyatakan dalam matrik 2 dimensi $f(x, y)$, di mana ' $x$ ' serta ' $y$ ' ialah koordinat pixel dalam matrik serta ' $f$ ' ialah derajat intensitas pixel tersebut [11].

\section{B.2. Pengolahan Citra}

Pengolahan citra didefinisikan sebagai suatu proses citra yang berdimensi dua yang bertujuan untuk memperbaiki kualitas dari suatu citra. Pengolahan citra mengubah suatu citra menjadi citra lain, artinya citra masukan menjadi citra yang kualitasnya lebih baik dari sebelumnya masukan [12]. Pengolahan citra digital yaitu proses untuk menganalisis citra komputer. Filter smoothing digunakan pada langkah preprocessing untuk memadukan dan mengurangi kebisingan pada suatu citra [12]. 


\section{B.3. Pengenalan Pola}

Pengenalan pola ialah suatu ilmu untuk mengelompokkan suatu citra atau objek berdasarkan fitur atau ciri-ciri yang dimiliki oleh objek tersebut. Pengenalan pola ini bertujuan untuk mendapatkan suatu jenis atau kategori berdasarkan ciri-ciri yang dimiliki objek tersebut. Oleh karena itu, pengenalan pola ini dapat memberikan perbedaan antara objek yang satu dengan yang lainnya [11]. Tahapan dari pengenalan pola adalah sebagai berikut :

- Preprocessing

Preprocessing bertujuan untuk meningkatkan kualitas suatu citra. Metode yang digunakan dalam preprocessing meliputi scaling, segmentasi, dan grayscale. Scaling adalah peningkatan atau penurunan ukuran piksel dalam suatu gambar. Segmentasi adalah sebuah langkah. Menghapus bagian gambar yang tidak perlu (latar belakang). Skala abuabu melibatkan pembuatan gambar dengan tiga lapisan RGB (Red Green Blue) menjadi citra grayscale (keabuabuan)[13].

\section{- Feature Extraction}

Tujuan feature extraction adalah untuk memperoleh informasi (karakteristik) tentang citra, dan ekstraksi objek merupakan proses penting dalam klasifikasi objek dalam pengenalan pola [13]. Citra daun yang diklasifikasi dengan baik dapat digunakan untuk mengidentifikasi jenis daun.

- Clasification

Classification adalah proses menemukan pola yang membedakan antara kelas latih yang digunakan untuk memprediksi kelas uji yang kelasnya belum diketahui. Metode klasifikasi yang banyak digunakan yaitu Rough Sets, Naive Bayes classifiers, Memory Based Reasoning, Neural Network, Classification Trees, K-Nearest Neighbor, Extreme Learning Machine, dan Support Vector Machines. Proses ini dilakukan agar data atau citra dapat dikategorikan dalam suatu kelas tertentu yang telah ditentukan [13].

\section{B.4.Deteksi Tepi}

Salah satu proses penting dalam pengolahan citra adalah deteksi tepi. Tepi citra dapat digunakan sebagai fitur atau karakteristik yang dapat digunakan dalam proses mengidentifikasi (mengidentifikasi dan mengenali), mengklasifikasikan dan menyempurnakan informasi dalam sebuah citra[14]. Tepi suatu objek berguna untuk segmentasi, menyelaraskan, dan mendefinisikan objek. Titik kontur adalah tempat di mana piksel berubah dari kekasaran menjadi skala abu-abu. Deteksi tepi adalah proses mendeteksi berbagai perubahan intensitas berbeda dalam sebuah bidang citra[15].

Deteksi tepi suatu citra akan menghasilkan tepi-tepi dari objek citra, tujuannya antara lain :

- Untuk menandai bagian yang menjadi detail citra.

- Meningkatkan detail citra yang buram.

- Adanya efek proses akuisisi citra.

- Mengonversi citra 2D menjadi bentuk kurva

Salah satu operator deteksi tepi adalah deteksi tepi canny. Salah satu metode deteksi tepi baru adalah operator
Canny. Operator Canny, diusulkan oleh John Canny pada tahun 1986, disebut sebagai operator deteksi tepi optimal.

\section{B.5.Fitur Canny Edge Detection}

Metode canny ialah metode yang paling optimal untuk deteksi tepi dibandingkan metode deteksi tepi lainnya[16]. Pada metode deteksi tepi ini menggunakan operator gaussian kernel untuk memperbaiki atau menghilangkan derau yang ada pada suatu citra, sehingga menghasilkan citra yang lebih halus. Deteksi tepi canny bertujuan untuk memperjelas suatu garis batas yang terdapat pada suatu obyek di dalam suatu citra[17]. Kriteria deteksi tepi yang optimal yang dapat dipenuhi oleh metode Canny yaitu :

- Dapat mendeteksi tepi dengan baik. Kemampuan untuk mengidentifikasi dan menandai semua tepi yang ada berdasarkan pemilihan parameter konvolusi. Jika diinginkan, sangat fleksibel dalam menentukan tingkat deteksi ketebalan tepi.

- Dapat menggunakan Canny untuk menghasilkan jarak minimum antara tepi yang terdeteksi dan tepi asli.

- Respon yang jelas. Sehingga mudah dideteksi dan tidak menimbulkan kebingungan dalam pengolahan citra selanjutnya, pengaturan Deteksi Tepi Canny memiliki pengaruh yang signifikan pada hasil tepi yang dihasilkan [17].

\section{Tahapan dari Canny Edge Detection[13]:}

- Penyaringan noise suatu citra, sehingga menghasilkan citra yang lebih halus menggunakan Gaussian Filter dengan sesuai dengan Persamaan (1).

$$
G(i, j)=\frac{1}{2 \pi \sigma^{2}} \cdot e^{-\frac{(i-u)^{2}+(j-v)^{2}}{2 \sigma^{2}}}
$$

- Mendapatkan kekuatan tepi (edge strength) dengan persamaan yang digunakan sesuai Persamaan (2).

$$
G=\sqrt{|G x|^{2}+|G y|^{2}}
$$

- Menentukan arah dari suatu tepi citra dengan menggunakan Persamaan (3).

$$
\delta=\tan ^{-1}\left(\frac{G^{y}}{G^{x}}\right)
$$

- Garis tepi diperkecil dengan menerapkan nonmaximus suppression.

Penghilangan non-maximum dilakukan di sepanjang tepi dan menghilangkan piksel - piksel yang tidak dianggap sebagai tepi. Hanya nilai maksimum yang ditandai sebagai batas. Sehingga didapatkan garis tepi yang lebih ramping [12].

- Binarisasi dengan menggunakan hysteresis thresholding.

Langkah ini mengevaluasi setiap piksel dengan menerapkan dua ambang batas, ambang batas rendah (T1) dan ambang batas tinggi (T2), apakah termasuk dalam kategori piksel tepi atau tidak. Nilai yang lebih kecil dari T1 diubah menjadi hitam (nilai 0), dan nilai 
yang lebih besar dari T2 diubah menjadi nilai putih 255)[12].

Pada penelitian ini menggunakan empat jenis ekstraksi fitur bentuk, di antaranya adalah :

- Area

Menghitung luas dari suatu citra atau menghitung nilai skalar dari jumlah piksel aktual daerah suatu citra dengan menggunakan Persamaan (4).

$$
\text { Area }=\sum_{i=1}^{n} \sum_{j=1}^{m} f(i, j)
$$

\section{- $\quad$ Perimeter}

Perbandingan antara keliling, panjang dan lebar daun ialah salah satu perhitungan yang digunakan untuk ekstraksi fitur dengan menggunakan Persamaan (5).

$$
P=\frac{p}{L p+W p}
$$

\section{- Eccentricity}

Menghitung nilai skalar yang memastikan eksentrisitas elips, Nilai pada eksentrisitas merupakan antara 0 serta 1 . Elips yang nilai eksentrisitasnya 0 merupakan lingkaran, sedangkan elips yang eksentrisitasnya 1 merupakan segmen garis dengan menggunakan Persamaan (6).

$$
\mathrm{e}=\sqrt{1-\frac{b^{2}}{a^{2}}}
$$

\section{- Matric}

Menghitung perbandingan antara luas serta keliling objek. Matric mempunyai rentang nilai antara 0 hingga 1. Matric mendekati 0 merupakan segmen garis sedangkan matric mendekati 1 merupakan lingkaran dengan menggunakan Persamaan (7).

$$
M=\frac{4 \pi x A}{C^{2}}
$$

\section{B.6. Fitur GLCM}

Gray Level Co-occurrence Matrix (GLCM) merupakan metode statistik dimana memakai citra yang berskala keabuan. kemudian menciptakan matrik co-occurrence dan dilanjutkan dengan merepresentasikan ikatan ketetanggaan antar piksel dalam suatu citra bersumber pada arah orientasi ataupun sudut serta jarak, langkah selanjutnya merupakan menciptakan matrik simetris dengan menambahkan menghasilkan matrik simetris dengan meningkatkan matrik co-occurrence dengan matrik transpose-nya. Setelah itu dicoba normalisasi terhadap matrik simetris dengan menghitung tiap elemen matrik. Langkah terakhir merupakan dengan menghitung fitur dari GLCM. Tiap fitur dihitung dengan satu piksel jarak di 4 arah , yaitu $0^{0}, 45^{\circ}$, $90^{\circ}$ dan $135^{\circ}$ untuk mengetahui co-occurrence[18]-[20]. Pada penelitian ini menggunakan empat jenis ekstraksi fitur tekstur, di antaranya:
- $\quad$ Angular Second Moment (ASM) atau Energy

ASM merupakan ukuran homogenitas dari suatu citra, dengan menggunakan Persamaan (8).

$$
A S M=\sum \sum(\operatorname{GLCM}(i, j)) 2
$$

\section{- Contrast}

Contrast merupakan ukuran keberadaan variasi aras keabuan piksel citra, dengan menggunakan Persamaan (9).

$$
\text { Contrast }=\sum \sum|i-j| 2 \operatorname{GLCM}(i, j)
$$

\section{- Entropy}

Entropy menyatakan ukuran ketidakteraturan aras keabuan di dalam citra, dengan menggunakan Persamaan (10).

$$
\text { Entropy }=\sum \sum(\operatorname{GLCM}(i, j)) \log (\operatorname{GLCM}(i, j))(10)
$$

\section{- Homogeneity}

Homogenity menyatakan ukuran kedekatan setiap elemen, dengan menggunakan Persamaan (11).

$$
\text { Homogeneity }=\sum \sum \frac{(\operatorname{GLCM}(i, j))}{1+|i-j|}
$$

\section{B.7. $k$-Nearest Neighbor ( $k N N)$}

Algoritme k-Nearest Neighbor (kNN) merupakan metode klasifikasi berdasarkan jarak k-tetangga terdekat atau metode yang mengklasifikasikan data baru berdasarkan data pembelajaran atau data pelatihan yang di mana jaraknya paling dekat dengan obyek yang telah dilatih tersebut. Algoritme k-Nearest Neighbor termasuk dalam kelas supervised learning bertujuan untuk menemukan model data baru dengan menghubungkan model data yang ada dengan data baru. Algoritme kNearest Neighbor bekerja sebagai prediksi berdasarkan pengklasifikasi tetangga berdasarkan data yang sudah di latih[2]. Cosine similarity yang digunakan untuk menghitung jarak antara dua vektor yang digunakan untuk memeriksa ukuran dapat digunakan sebagai interpretasi kedekatan jarak antara dua objek dinyatakan dalam suatu Persamaan (12):

$$
\cos a=\frac{A . B}{|| A|||B|}=\frac{\sum_{i=1}^{n} A_{i} \times B_{j}}{\sqrt{\sum_{i=1}^{n}\left(A_{i}\right)^{2}} \times \sqrt{\sum_{i=1}^{n}\left(B_{j}\right)^{2}}}
$$

Diperlukan perhitungan akurasi untuk evaluasi dari suatu model yang telah dikembangkan. Pengukuran akurasi dapat menggunakan perhitungan recognition rate. Persamaan recognition rate yang digunakan dapat dilihat pada Persamaan (13):

$$
\text { Accuracy }=\frac{\text { the correct of data }}{\text { total data }} \times 100
$$

\section{B.8. Daun}

Daun merupakan bagian dari tubuh tumbuhan yang dapat digunakan untuk mengidentifikasi jenis dari 
tumbuhan. Klasifikasi daun ini dapat dilakukan dengan cara pengenalan pola bentuk struktural dan juga tekstur dari citra daun tersebut. Bentuk dan struktur dapat digunakan sebagai masukan dalam mengidentifikasi citra daun. Spesies-spesies daun yang digunakan pada penelitian ini yaitu, spesies Acer buergerianum, Aesculus chinensis, Cinnamomum japonicum Sieb, Kalopanax septemlobus, Phoebe nanmu (Olive.) Gamble, Pittosporum tobira (Thunb.) Ait.f., Prunus serrulata Lindl. Var.

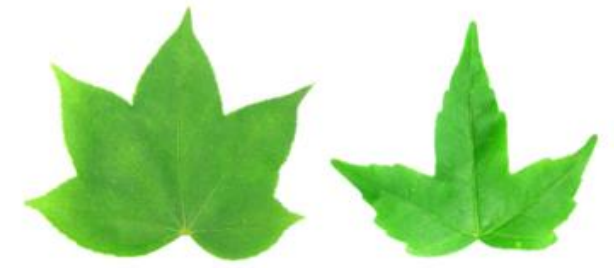

Gambar 1. Dataset daun flavia [1]

\section{METODOLOGI PENELITIAN}

\section{A. Perancangan Sistem}

Di dalam sub bab ini dijelaskan bagaimana sistem Analisis Pengenalan Pola Daun ini dirancang mulai dari tahapan pelatihan citra hingga sistem dapat mengetahui akurasi optimal dari citra latih dan citra uji. Blok diagram sistem pengenalan pola daun disajikan pada Gambar 2.

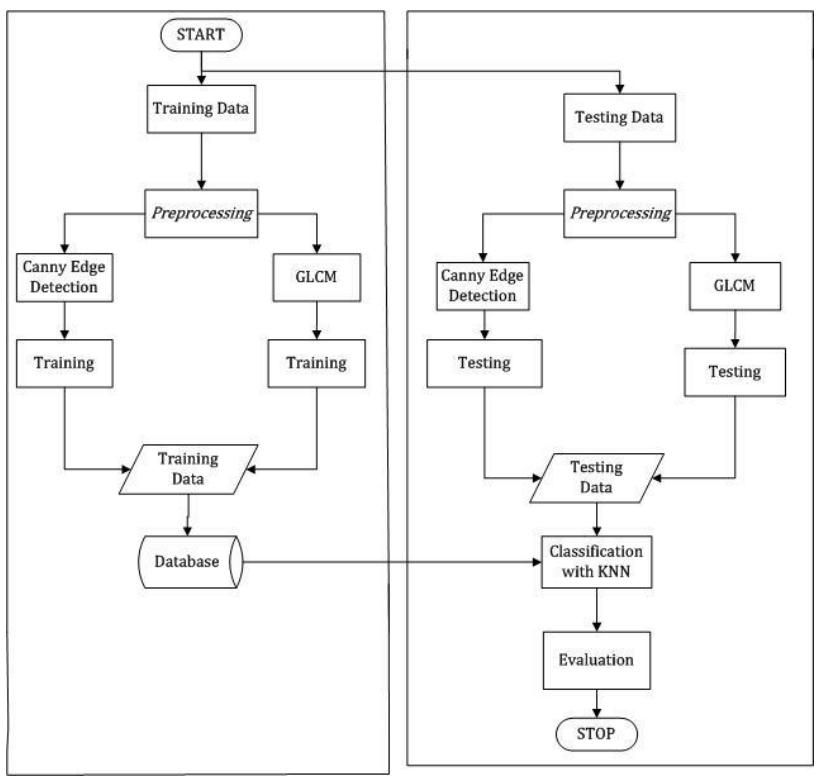

Gambar 2. Diagram sistem pengenalan pola daun

\section{A.1. Dataset}

Dataset citra daun Flavia terdiri dari 33 spesies citra daun dan total 1.907 data citra daun, penelitian ini menggunakan 50 data citra daun dari 7 spesies, dengan total keseluruhan data citra daun yang digunakan sebanyak 350 data citra[1]. Pemilihan 7 spesies daun pada penelitian ini mengacu pada penelitian sebelumnya, di mana sudah terdapat nama spesies daun, namun hanya 7 spesies yang diketahui, dikarenakan pada citra daun Flavia ini tidak terdapat nama-nama spesies daun tersebut.

\section{A.2.Preprocessing}

Terdapat beberapa langkah yang dilakukan untuk preprocessing yaitu melakukan scaling dengan mengubah ukuran dari dataset asli citra daun Flavia. Setelah melakukan scaling selanjutnya melakukan segmentasi yaitu menghilangkan bagian-bagian dari citra yang tidak diperlukan dan selanjutnya citra RGB diubah menjadi citra grayscale.

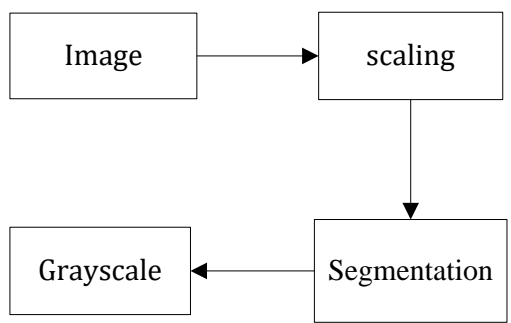

Gambar 3. Tahapan preprocessing

Tahap awal dari preprocessing ini dengan mengubah ukuran citra asli dataset Flavia dengan ukuran awal $1600 \mathrm{x}$ 1200 akan di resize menjadi $64 \times 128,32 \times 64$ dan $128 \times$ 256[20]. Pembagian citra menjadi beberapa ukuran untuk menentukan resolusi spesial yang diperoleh dan juga bertujuan untuk mempercepat proses komputasi menjadi lebih cepat. Hasil dari preprocessing disajikan pada Gambar 4.

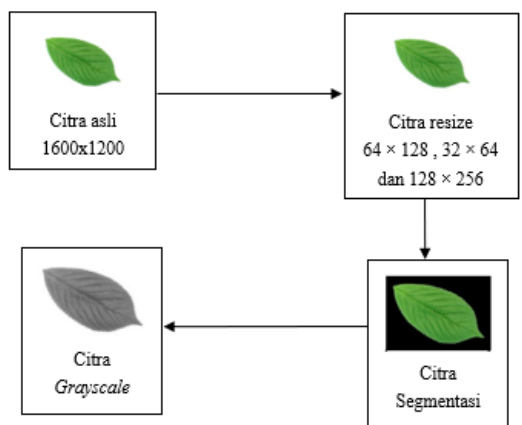

Gambar 4. Tahapan hasil preprocessing

\section{A.3. Ekstraksi Fitur}

Setelah melalui tahap preprocessing selanjutnya melakukan ekstraksi fitur canny edge detection dengan tahapan melakukan smoothing dengan menggunakan Gaussian filter, finding gradien, non-maximum suppression, double thresholding, dan edge tracking by hysteresis. Setelah melakukan tahapan-tahapan canny edge detection selanjutnya melakukan ekstraksi fitur bentuk dengan menghitung menghitung nilai area, perimeter, eccentricity dan matric. Sama halnya dengan canny, setelah processing dilakukan juga proses ekstraksi fitur tekstur dengan menggunakan GLCM dengan sudut $0^{\circ}, 45^{\circ}, 90^{\circ}$ dan $135^{\circ}$, kemudian menghitung empat fitur tekstur yaitu contrast, homogenity, energy, dan entropy. Setelah semua nilai fitur didapatkan maka akan dilakukan klasifikasi dengan metode $\mathrm{kNN}$. 


\section{A.4.Klasifikasi}

Proses klasifikasi yang dilakukan dalam penelitian ini menggunakan metode k-Nearest Neighbor (kNN) dengan menggunakan nilai k sama dengan 3, 5 dan 7. k-Nearest Neighbor $(\mathrm{kNN})$ merupakan teknik pencarian berdasarkan $\mathrm{k}$ tetangga terdekat. Pemilihan nilai $\mathrm{k}$ ganjil untuk menghindari kemungkinan hasil klasifikasi sulit ditentukan karena masing-masing kelas memiliki jumlah yang sama.

\section{A.5. Skenario Pengujian}

Skenario pengujian dilakukan dengan dua skenario yang berbeda yakni :

- Skenario pengujian pertama : Pada proses pelatihan, data yang digunakan yaitu dengan perbandingan 70:30, 80:20 dan 90:10 dengan data dipilih secara random.

- Skenario pengujian kedua : Proses pengujian menggunakan repeated $\mathrm{k}$-fold cross validation, digunakan repeated 5-fold cross validation dengan pengujian dilakukan sebanyak 5 kali. Variasi cross validation yang digunakan yaitu variasi repeated dengan indeks yang berbeda-beda dengan membagi dataset yang berjumlah 350 data yang terbagi menjadi data latih dan data uji menjadi 5 subset yang masingmasing subset berjumlah 70 data.

\section{Fold testing $\square$ Fold training}

\begin{tabular}{|l|l|l|l|l|}
\hline f1 & f2 & f3 & f4 & f5 \\
\hline f1 & f2 & f3 & f4 & f5 \\
\hline f1 & f2 & f3 & f4 & f5 \\
\hline f1 & f2 & f3 & f4 & f5 \\
\hline f1 & f2 & f3 & f4 & f5 \\
\hline
\end{tabular}

Gambar 5. Ilustrasi 5-fold cross validation

\section{A.6.Waktu Komputasi}

Waktu komputasi merupakan metode yang dipilih untuk mengukur waktu yang dibutuhkan oleh model untuk melakukan proses pengenalan. Waktu komputasi ini meliputi waktu yang diperlukan oleh program untuk melakukan training dan testing. Waktu komputasi dihitung sejak proses pelatihan dan juga melakukan pengujian dimulai hingga proses terhenti.

\section{HASIL DAN PEMBAHASAN}

Proses pengujian ini dicoba untuk mengenali serta menganalisis performa dari metode yang diterapkan dalam identifikasi citra daun menggunakan fitur canny edge detection serta GLCM, dan seberapa besar pengaruh penggabungan kedua fitur tersebut dengan memakai metode klasifikasi kNN. Pengujian dilakukan pada tahap ekstraksi fitur dan tahap klasifikasi. Hasil ekstraksi fitur tersebut digunakan sebagai data masukan untuk klasifikasi citra daun.

Informasi citra daun yang digunakan dalam riset ini berupa dataset sebanyak 350 citra yang terdiri dari 7 spesies dengan 50 citra daun tiap spesies. Citra daun tersebut dibagi jadi 2 bagian ialah data pelatihan serta data pengujian dan akan digunakan dalam proses ekstraksi fitur menggunakan fitur canny edge detection dan GLCM serta tahap klasifikasi citra daun menggunakan metode kNearest Neighbour.

\section{A. Pengujian dengan Ekstraksi Fitur Canny}

Pengujian ini dilakukan dengan metode ekstraksi fitur deteksi tepi Canny dengan 4 fitur yaitu area, perimeter, eccentricity dan matric. Canny pada penelitian ini bertujuan sebagai deteksi tepi bentuk untuk memperjelas detail dari citra dan dapat menghasilkan citra yang optimal. Fitur-fitur yang dihasilkan dari ekstraksi fitur canny ini kemudian akan digunakan sebagai masukan untuk klasifikasi dari citra yang diidentifikasi. Uji coba ini menggunakan klasifikasi kNN sesuai dengan metode klasifikasi yang digunakan pada penelitian ini. Hasil dari pengujian dapat dilihat pada Tabel I.

TABEL I. Pengujian DENGan Ekstraksi Fitur CANny

\begin{tabular}{|c|c|c|c|}
\hline Nilai $\mathbf{k}$ & $\mathbf{3}$ & $\mathbf{5}$ & $\mathbf{7}$ \\
\hline $32 \times 64$ & & & \\
\hline $64 \times 128$ & $75 \%$ & $77,1 \%$ & $77,1 \%$ \\
\hline $128 \times 256$ & $\mathbf{8 0 \%}$ & $75,2 \%$ & $75,2 \%$ \\
\hline
\end{tabular}

Hasil pengujian pada Tabel I, didapatkan bahwa nilai $\mathrm{k}$ pada klasifikasi kNN dan ukuran citra mempengaruhi akurasi pada pengujian classifier canny untuk mengidentifikasi citra bentuk daun di mana, akurasi tertinggi pada citra berukuran $128 \times 256$ pada parameter $\mathrm{k}$ sama dengan 3 dengan akurasi klasifikasi tertinggi $80 \%$. Hasil klasifikasi dengan ekstraksi fitur canny pada setiap ukuran piksel citra, dilihat kecenderungan nilai akurasi akan berkurang bertambahnya nilai k pada klasifikasi kNN. Perbedaan itu disebabkan karena persebaran data yang berbeda di masing-masing kelas dan perbedaan ukuran citra yang dijadikan sebagai masukan pada penelitian ini untuk mendapatkan tingkat keberhasilan dan keakuratan gambar, semakin besar ukuran citra masukan piksel, semakin baik keluaran yang dihasilkan pada saat ekstraksi fitur. Sedangkan bila dibandingkan dengan penelitian [13] sebelumnya yang dijadikan acuan pada penelitian ini menggunakan fitur eccentricity, perimeter, area (regioprops) dan area (bware) dengan ukuran citra yaitu 256x256 mendapatkan akurasi klasifikasi 79\% pada k kNN sama dengan 3. Perbandingan dari hasil akurasi keduanya tidak memiliki perbedaan yang signifikan dengan menggunakan fitur-fitur yang hampir sama pada penelitian sebelumnya.

\section{B. Pengujian dengan Ekstraksi Fitur GLCM}

Uji coba yang dilakukan pada tahap ini yaitu dengan menggunakan metode ekstraksi tekstur GLCM sudut $0^{0}$, $45^{\circ}, 90^{\circ}$ dan $135^{\circ}$ dengan 4 fitur yaitu energy, entropy, contrast dan homogenity. GLCM pada penelitian ini bertujuan sebagai ekstraksi ciri tekstur yang menentukan 
karakteristik mengenai susunan struktur permukaan dari citra daun yang mengandung informasi ciri tekstur dari citra yang diidentifikasi. Fitur-fitur yang dihasilkan dari ekstraksi ciri tekstur GLCM ini kemudian akan digunakan sebagai masukan proses klasifikasi dari citra yang diidentifikasi. Hasil dari pengujian dapat dilihat pada Tabel II.

TABEL II. Pengujian dengan Ekstraksi Fitur GLCM

\begin{tabular}{|c|c|c|c|}
\hline Ukuran citra & 3 & 5 & 7 \\
\hline $32 \times 64$ & $87,6 \%$ & $88,5 \%$ & $86,6 \%$ \\
\hline $64 \times 128$ & $92,3 \%$ & $91,4 \%$ & $90,4 \%$ \\
\hline $128 \times 256$ & $93,3 \%$ & $88,5 \%$ & $88,5 \%$ \\
\hline
\end{tabular}

Hasil pengujian pada Tabel II didapatkan bahwa nilai $\mathrm{k}$ pada $\mathrm{kNN}$ dan ukuran citra mempengaruhi akurasi pada pengujian classifier tekstur GLCM untuk mengidentifikasi tekstur daun. Pada pengujian ini menghasilkan akurasi klasifikasi tertinggi pada citra masukan berukuran $128 \times 256$ dan parameter $\mathrm{k} \mathrm{kNN}$ sama dengan 3 dengan akurasi klasifikasi 93,3\%. Hasil klasifikasi dengan kNN sangat bergantung pada nilai $\mathrm{k}$ pada klasifikasi dan hasil ekstraksi tekstur GLCM pada setiap ukuran piksel citra, dilihat kecenderungan nilai akurasi klasifikasi akan berkurang dengan bertambahnya nilai $\mathrm{k}$ pada klasifikasi $\mathrm{kNN}$. Perbedaan itu disebabkan karena persebaran data yang berbeda di masing-masing kelas dan perbedaan ukuran citra yang dijadikan sebagai masukan pada penelitian ini untuk mendapatkan tingkat keberhasilan dan keakuratan gambar, semakin besar ukuran citra masukan piksel, semakin baik keluaran yang dihasilkan pada saat ekstraksi fitur.

\section{Pengujian dengan Ekstraksi Fitur Canny dan GLCM}

Pengujian ini dilakukan dengan menggabungkan kedua fitur Canny dan GLCM untuk mengetahui apakah penggabungan kedua fitur ini menghasilkan hasil akurasi yang meningkat untuk mengidentifikasi citra daun. Pengujian ini menggunakan klasifikasi kNN sesuai dengan metode klasifikasi yang digunakan pada penelitian ini. Hasil dari pengujian dapat dilihat pada Tabel III.

TABEL III. Pengujian dengan Ekstraksi Fitur CAnNy dan GLCM

\begin{tabular}{|c|c|c|c|}
\hline Nilai k & $\mathbf{3}$ & $\mathbf{5}$ & $\mathbf{7}$ \\
\hline Ukuran citra & & & $88,5 \%$ \\
\hline $32 \times 64$ & $88,5 \%$ & $89,5 \%$ & $88,5 \%$ \\
\hline $64 \times 128$ & $93,3 \%$ & $91,4 \%$ & $96,2 \%$ \\
\hline $128 \times 256$ & $\mathbf{9 8 \%}$ & $95,2 \%$ & \\
\hline
\end{tabular}

Hasil pengujian pada Tabel III, didapatkan bahwa nilai $\mathrm{k}$ pada $\mathrm{kNN}$ dan ukuran citra mempengaruhi akurasi pada pengujian fitur Canny dan GLCM untuk mengidentifikasi citra daun. Pada pengujian ini menghasilkan akurasi tertinggi mencapai $98 \%$ yaitu dengan nilai $\mathrm{k}$ pada $\mathrm{kNN}$ sama dengan 3 dan citra berukuran 128x256.
Hasil klasifikasi dengan kNN sangat bergantung pada nilai $\mathrm{k}$ pada klasifikasi dan melakukan penggabungan kedua fitur canny dan GLCM pada setiap ukuran piksel citra, dilihat kecenderungan nilai akurasi klasifikasi akan berkurang dengan bertambahnya nilai $\mathrm{k}$ pada klasifikasi kNN. Perbedaan itu disebabkan karena persebaran data yang berbeda di masing-masing kelas dan perbedaan ukuran citra yang dijadikan sebagai masukan pada penelitian ini untuk mendapatkan tingkat keberhasilan dan keakuratan gambar, semakin besar ukuran citra masukan piksel, semakin baik keluaran yang dihasilkan pada saat ekstraksi fitur.

Pada penelitian ini terkait dengan penggabungan kedua fitur canny dan GLCM, di mana kedua metode ekstraksi fitur ini merupakan feature detector, di mana kedua metode ekstraksi fitur ini memuat informasi yang berbeda dan dijadikan sebagai masukan untuk klasifikasi. Percobaan dengan menggabungkan kedua metode ekstraksi fitur canny dan GLCM mendapatkan hasil akurasi klasifikasi yang meningkat dibandingkan dengan hasil klasifikasi dengan menggunakan ekstraksi fitur secara terpisah pada pengujian sebelumnya.

\section{Hasil Pengujian}

Pengamatan terhadap hasil pengujian dilakukan secara berurutan sesuai dengan urutan yang telah dijabarkan pada skenario pengujian. Pada pengujian ini menggunakan satu jenis ukuran citra karena, pada uji coba sebelumnya menghasilkan akurasi klasifikasi tertinggi pada citra berukuran 128x256 dan dengan nilai k klasifikasi kNN sama dengan 3. Adapun arsitektur awal untuk pengujian pertama yaitu dengan melakukan split validation dengan perbandingan data latih dan data uji 70:30, 80:20, 90:10. Selanjutnya, untuk mengetahui performa model adalah dengan pengujian repeated $\mathrm{k}$-fold cross validation, pada penelitian ini menggunakan repeated 5-fold cross validation, pemilihan nilai k pada pengujian ini yaitu terkait dengan variasi data latih dan uji yang akan berulang kali sebanyak nilai $\mathrm{k}$ yang digunakan. Untuk data yang digunakan pada penelitian ini sebanyak 350 data yang akan terbagi menjadi data training dan data testing menjadi 5 subset yang masing-masing subset berjumlah 70 data, dengan repeated 5-fold cross validation 5 kaliakan diulang sebanyak 5 kali, sehingga akan melakukan 25 kali pengulangan pada masing-masing record yang berbeda dan akan digunakan untuk memperkirakan keefektifan model. Namun, jika menggunakan nilai k yang lebih tinggi maka akan dapat mengurangi estimasi variasi data tersebut atau tidak akan memiliki sample yang cukup dalam set validasi untuk mengevaluasi model dengan baik.

\section{D.1. Pengujian dengan Split Validation}

Pada pengujian ini dilakukan pengambilan data latih dan data uji secara acak dengan variasi data berdasarkan perbandingan 70:30, 80:20 dan 90:10 dari dataset yang ada. Dari pengujian variasi data, nilai k yang akan digunakan adalah 3, 5 dan 7. Hasil pengujian dengan citra random dilihat pada Tabel IV. 
TABEL IV. Pengujian dengan Split Validation

\begin{tabular}{|c|c|c|c|}
\hline $\begin{array}{c}\text { Variasi data } \\
\text { training dan } \\
\text { testing }\end{array}$ & Nilai k & $\begin{array}{c}\text { Akurasi } \\
\text { Training }\end{array}$ & $\begin{array}{c}\text { Akurasi } \\
\text { Testing }\end{array}$ \\
\hline \multirow{4}{*}{$70: 30$} & 3 & $\mathbf{9 9 , 1 \%}$ & $\mathbf{9 8 \%}$ \\
\cline { 2 - 4 } & 5 & $95,5 \%$ & $95,2 \%$ \\
\cline { 2 - 4 } & 7 & $95,1 \%$ & $96,1 \%$ \\
\hline \multirow{3}{*}{$80: 20$} & 3 & $98,8 \%$ & $97,1 \%$ \\
\cline { 2 - 4 } & 5 & $96,7 \%$ & $95,7 \%$ \\
\cline { 2 - 4 } & 7 & $96 \%$ & $95,7 \%$ \\
\hline \multirow{3}{*}{$90: 10$} & 3 & $99 \%$ & $100 \%$ \\
\cline { 2 - 4 } & 7 & $96,8 \%$ & $100 \%$ \\
\cline { 2 - 4 } & 5 & $96,5 \%$ & $100 \%$ \\
\hline
\end{tabular}

Berdasarkan Tabel IV, didapatkan bahwa variasi jumlah data latih dan data uji serta nilai k pengaruhi akurasi pada sesi pengujian, dengan menggunakan tiga variasi jumlah data latih dan data uji menghasilkan tingkatan akurasi yang berbeda bersumber pada nilai $\mathrm{k}$ yang digunakan. Berdasarkan variasi data yang digunakan menghasilkan akurasi tertinggi pada training $99 \%$ dan testing mencapai $100 \%$ dengan variasi data latih dan data uji 90:10 dan nilai k sama dengan 3. Pada pengujian ini, dengan jumlah data training yang semakin banyak maka semakin baik kinerja model yang dihasilkan dan pengaruh pada penggunaan nilai $\mathrm{k}$ pada klasifikasi $\mathrm{kNN}$ tidak signifikan perbedaannya pada masing-masing nilai $\mathrm{k}$ pada variasi data latih dan uji. Namun, dengan penggunaan nilai $\mathrm{k}$ yang semakin kecil akan mendapatkan hasil akurasi klasifikasi yang tinggi karena, persebaran data yang sedikit untuk menentukan ketetanggaan terdekat pada $\mathrm{kNN}$.

\section{D.2. Pengujian dengan Repeated k-Fold Cross Validation}

Pada pengujian ini untuk mengetahui performa model klasifikasi adalah dengan repeated $k$-fold cross validation. Pada penelitian ini menggunakan repeated 5-fold cross validation. Hasil akurasi dari repeated 5-fold cross validation disajikan pada Tabel V.

TABEL V. Pengujian DENGAN RePEATEd K-Fold CRossVALIDATION

\begin{tabular}{|c|c|c|}
\hline Ukuran citra & Nilai k & Akurasi rata-rata \\
\hline \multirow{3}{*}{$32 \times 64$} & 3 & $86 \%$ \\
\cline { 2 - 3 } & 5 & $85,4 \%$ \\
\cline { 2 - 3 } & 7 & $84,9 \%$ \\
\hline \multirow{3}{*}{$64 \times 128$} & 3 & $94,2 \%$ \\
\cline { 2 - 3 } & 5 & $93,2 \%$ \\
\cline { 2 - 3 } & 7 & $93 \%$ \\
\hline \multirow{3}{*}{$128 \times 256$} & 3 & $95 \%$ \\
\cline { 2 - 3 } & 5 & $94,7 \%$ \\
\cline { 2 - 3 } & 7 & $94,2 \%$ \\
\hline
\end{tabular}

Berdasarkan Tabel $\mathrm{V}$, didapatkan bahwa nilai $\mathrm{k}$ pada kNN dan ukuran citra mempengaruhi akurasi pada tahap pengujian dengan 5-fold cross validation. Berdasarkan hasil pengujian yang telah dilakukan, didapatkan kombinasi data terbaik dengan hasil akurasi rata-rata $95 \%$ dengan nilai $\mathrm{K}$ sama dengan 3 pada citra berukuran $128 \mathrm{x}$ 256 , dalam setiap pengujian yang dilakukan ukuran citra mempengaruhi tingkat akurasi klasifikasi. Tujuan melakukan pengujian dengan repeated 5-fold cross validation menghindari tumpang tindih pada data testing pada masing-masing iterasi, pengujian ini menghasilkan performa yang stabil karena, proses dilakukan berulang kali sampai 5 kali record, sehingga semua record data mendapatkan bagian menjadi data testing. Dengan repeated 5-fold cross validation 5 kali lipat akan diulang sebanyak 5 kali, sehingga akan melakukan 25 kali pengulangan pada masing-masing record yang berbeda dan digunakan untuk memperkirakan keefektifan model dalam melakukan klasifikasi

\section{D.3. Pengujian terhadap Ukuran Citra}

Ukuran citra merupakan bagian yang diatur di dalam persiapan sebelum melakukan proses testing atau bisa disebut sebagai bagian yang ditentukan pada tahap preprocessing. Semakin kecil ukuran citra maka detail dari citra itu sendiri semakin tidak terlihat. Pada penelitian ini akan uji 3 ukuran citra yaitu $32 \times 64,64 \times 128$ dan $128 \times 256$. Hasil dari pengujian dapat dilihat pada Tabel VI.

TABEL VI. PengujIAN Terhadap UkURAN Citra

\begin{tabular}{|c|c|c|c|}
\hline Ukuran citra & Nilai K & Akurasi & $\begin{array}{c}\text { Waktu } \\
\text { komputasi }\end{array}$ \\
\hline $32 \times 64$ & 3 & $86 \%$ & $550,38 \mathrm{~s}$ \\
\hline $64 \times 128$ & 3 & $94,2 \%$ & $614,96 \mathrm{~s}$ \\
\hline $128 \times 256$ & 3 & $95 \%$ & $948,69 \mathrm{~s}$ \\
\hline
\end{tabular}

Pada Tabel VI, menunjukkan hasil pengujian waktu komputasi berdasarkan ukuran citra. Parameter nilai k pada klasifikasi kNN sama dengan 3 menghasilkan akurasi tertinggi, parameter ini berdasarkan pada pengujianpengujian yang telah dilakukan sebelumnya berdasarkan hasil akurasi klasifikasi yang di dapatkan. Ukuran citra 32x64 memberikan waktu tercepat dalam proses pelatihan dengan membutuhkan waktu 550,38 detik. Waktu komputasi tersebut memiliki perbedaan yang signifikan dibandingkan dengan waktu yang dibutuhkan oleh ukuran citra 64x128 yaitu 614,69 detik dan citra 128x256 membutuhkan waktu paling lama yaitu 948,69 detik. Berdasarkan hasil uji tersebut maka untuk ukuran citra yang paling baik pada citra berukuran 128x256 karena, semakin besar ukuran citra maka detail dari citra tersebut akan semakin baik.

\section{KESIMPULAN DAN SARAN}

Berdasarkan hasil pengujian yang telah dilakukan, pengembangan pengenalan pola daun sudah berjalan dengan baik dengan menggunakan fitur Canny dan GLCM, hasil performa klasifikasi dengan fitur GLCM 
lebih baik dari pada hasil klasifikasi dengan fitur canny, dengan akurasi yang diperoleh klasifikasi dengan fitur GLCM yaitu 93,3\% dan hasil akurasi klasifikasi fitur deteksi tepi canny adalah $80 \%$ serta kombinasi kedua fitur ini menghasilkan akurasi yang meningkat yaitu $98 \%$ hingga $100 \%$ berdasarkan variasi data latih dan data uji yang digunakan pada pengujian klasifikasi dengan akurasi tertinggi pada parameter $\mathrm{k} \mathrm{kNN}$ sama dengan 3. Dapat disimpulkan bahwa sistem usulan telah berhasil dengan baik mengidentifikasi citra daun dengan kombinasi ekstraksi fitur menggunakan fitur canny dan fitur GLCM serta metode klasifikasi k-Nearest Neighbor.

Penelitian ini dapat dikembangkan dengan menambahkan jumlah dataset untuk masing-masing spesies sehingga classifier dapat mempelajari lebih banyak citra daun dan dapat mengidentifikasi jenis-jenis daun lainnya. Pengambilan citra dataset daun dengan menggunakan sudut pandang yang berbeda agar sistem dapat mengidentifikasi bentuk daun dari sisi lain.

\section{DAFTAR PUSTAKA}

[1] A. Hidayat and Makhsun, "Analisis Citra Daun Berdasarkan Fitur Local Binary Pattern Dan Fitur Canny Edge Detection Menggunakan Metode Klasifikasi KNearest Neighbor ( K-NN )," J. Esit, pp. 1-10, 2018.

[2] F. Liantoni, "Klasifikasi Daun Dengan Perbaikan Fitur Citra Menggunakan Metode K-Nearest Neighbor," Ultim. Comput., 2015.

[3] M. Muchtar and L. Cahyani, "Klasifikasi Citra Daun dengan Metode Gabor Co-Occurence," J. Ultim. Comput., vol. 7, no. 2, pp. 39-47, 2016.

[4] R. Rahmadewi, V. Efelina, E. Purwanti, and T. F. Ext, "IDENTIFIKASI JENIS TUMBUHAN MENGGUNAKAN CITRA DAUN BERBASIS JARINGAN SARAF TIRUAN ( ARTIFICIAL NEURAL NETWORKS )," vol. VII, no. 2, pp. 38-43.

[5] F. Fatimah, G. F. Laxmi, and P. Eosina, "Pengubahan Data Image Ikan Air Tawar ke Data Vektor menggunakan Edge Detection Metode Canny," J. Ris. Pendidik. Mat., vol. 9, pp. 55-60, 2017.

[6] P. Soepomo, "Implementasi Metode Canny Untuk Deteksi Tepi Mutu Daun Tembakau," J. Sarj. Tek. Inform., vol. 2, no. 3, pp. 231-243, 2014.

[7] M. Widyaningsih, "Identifikasi Kematangan Buah Apel Dengan Gray Level Co - Occurrence Matrix ( GLCM ), $J$. SAINTEKOM, vol. 6, no. 1, pp. 71-88, 2016.
[8] Y. P. Pasrun, C. Fatichah, and N. Suciati, "Penggabungan Fitur Bentuk dan Fitur Tekstur yang Invariant terhadap Rotasi untuk Klasifikasi Citra Pap Smear,” pp. 11-20, 2015.

[9] Subairi, Rahmadwati, and E. Yudaningtyas, "Implementasi Metode k-Nearest Neighbor pada Pengenalan Pola Tekstur Citra Saliva untuk Deteksi Ovulasi," J. EECCIS, vol. 12, no. 1, pp. 9-14, 2018.

[10] R. K. Dewi and N. Suciati, "Klasifikasi Tanaman berdasarkan Fitur Bentuk dan Tekstur pada Daun menggunakan Decision Tree," J. Cybermatika, vol. 3, no. 2, pp. 9-15, 2015.

[11] F. Flaurensia, T. Rismawan, and R. Hidayati, "Pengenalan Motif Batik Indonesia Menggunakan Deteksi Tepi Canny Dan Template Matching," J. Coding, Sist. Komput. Untan, vol. 4, no. 2, pp. 130-140, 2016.

[12] I. D. Kurniawati and A. Kusumawardhani, "Implementasi Algoritma Canny dalam Pengenalan Wajah menggunakan Antarmuka GUI Matlab," no. December, pp. 3-8, 2017.

[13] R. Andrian, S. Anwar, M. A. Muhammad, and A. Junaidi, "Identifikasi Kupu-Kupu Menggunakan Ekstraksi Fitur Deteksi Tepi ( Edge Detection ) dan Klasifikasi K-Nearest Neighbor ( KNN )," Jutisi (Jurnal Tek. Inform. dan Sist., vol. 5, pp. 234-243, 2019.

[14] I. Hastuti, "Perbandingan Metode Deteksi Tepi Menggunakan Metode Canny, Prewitt Dan Sobel Pada Image Ikan,” J. Repos. Poliban, vol. 5662, pp. 9-10, 2016.

[15] J. W. Yodha and A. W. Kurniawan, "Perbandingan Penggunaan Deteksi Tepi Dengan Metode Laplace, Sobel Dan Prewit Dan Canny Pada Pengenalan," J. Teknol. Inf., vol. 13, no. 3, pp. 189-197, 2014.

[16] L. H. Harefa, "Analisis Edge Detection Citra Digital Dengan Menggunakan Metode Robert Dan Canny," J. Ris. Komput., vol. 3, no. 1, pp. 29-34, 2016.

[17] A. N. Hermana and M. S. Juerman, "Implementasi Algoritma Canny dan Backpropagation dalam Pengenalan Pola Rumah Adat," J. Itenas, pp. 1-10, 2014.

[18] S. A. Wibowo, B. Hidayat, and U. Sunarya, "Simulasi dan Analisis Pengenalan Citra Daging Sapi dan Daging Babi dengan Metode GLCM," J. Seniati, no. 2, pp. 338-343, 2016.

[19] A. Kadir and A. Susanto, Teori dan Aplikasi Pengolahan Citra, no. January 2013. 2013.

[20] N. C. Siantar, J. Hendryli, and D. E. Herwindiati, "Aplikasi Mobile Berbasis CBIR Untuk Pancarian Produk Ponsel dan Onlineshop," J. Ilmu Komput. dan Sist. Inf., vol. 7, no. 1, pp. 92-98, 2019. 